\title{
The Impact of Influencer Marketing on Brand Engagement: A Conceptual Framework
}

\author{
Siti Liu ${ }^{1, *}$ \\ ${ }^{1}$ Graduate School, Chinese Academy of Social Science, No. 11 Changyu Street, Fangshan District, Beijing, China \\ *Corresponding author. Email: sl0061@bravemail.uncp.edu
}

\begin{abstract}
With the development of social media, influencer marketing has become a new and efficient brand marketing strategy that interests marketing managers. To better understand the impact of influencer marketing on brand engagement, this paper proposes a dual-route effect research framework based on prior literature. The model suggests that the parasocial relationship positively affects the source credibility during the content interaction between the audience and the influencer, and then the source credibility enhances brand credibility. In addition, content immersion increases brand content enjoyment. Both brand credibility and brand content enjoyment would ultimately cultivate brand engagement. The paper provides a potential framework of influencer marketing evaluation for future research and gives managerial implications.
\end{abstract}

Keywords: Influencer marketing, brand engagement, parasocial relationship, credibility, immersion.

\section{INTRODUCTION}

The development of social media platforms significantly expands individuals' impact by enabling people to have extra channels for expressing personal values and gaining the audience's attention. With social media empowerment, some individuals could share their lives, interests, and opinions, attract many audiences with their unique personalities, i.e., gradually develop into influencers [1]. Influencers can attract homogeneous mass audiences and easily shape and change fans' lifestyles and even perceptions and attitudes towards branding trends. Influencer marketing refers to promoting products and services to followers on social media through influencers to make consumers recognize the brand and encourage consumer interest and beneficial responses. Therefore, as brands realize and appreciate the potential of influencers, influencer marketing practices are multiplying at a fast rate [2]. In addition, millennials are more eager for fun and social interaction and tend to devote more time and enthusiasm to individuals and contents they favor [3]. Therefore, through the connection and interaction with influencers, consumers may have a closer bonding towards the brand and realize the followers' engagement and co-creation on social media, forming a viral spread of brand information.

Although companies have been exploring influencer marketing practices, related research is still in the early stage [4]. There is insufficiency in scholarly works on influencer marketing activities' processes and the psychological mechanism that makes the audience become potential consumers and continue to engage with the brand. Moreover, companies still doubt the certainty and effectiveness of influencer marketing. Practically the marketing results may be very different when choosing different types of influencers and platforms [5]. Therefore, it is crucial to understand the mechanism behind marketing process from influencer guidance to brand engagement. This research aims to clarify how influencer marketing in social media affects audience's brand engagement and explores which factors may motivate influencer marketing to elevate brand engagement.

\section{BACKGROUND}

\subsection{Influencer marketing}

Social media refers to a highly interactive platform that allows individuals and communities to create and share user-generated content and communicate with other users. On social media, influencers are both content generators and celebrities with many followers. Unlike traditional celebrities or public figures, social mediabased influencers are "regular people" who express themselves more personally on the platform [6] and focus 
on niche areas where they interest, e.g., technology, fashion, fitness, food, subculture. They can build a relationship with the audience by sharing their daily lives, knowledge, information and having conversations with others on social media to show themselves. Influencer marketing refers to a digital commercial strategy in which brand managers cooperate with famous influencers related to their brand positioning to implement brand promotion to target customers [7]. With a considerable fan base established, influencers can act as effective marketing agents, regularly publishing valuable content on social media for brand endorsement and cultivating many followers with marketing value.

The role of influencers is considered the source of information on social media, and consumers often refer to the information published by influencers before making a purchase. Scholars believe that the success of influencer marketing in social media is due to the high credibility [8]. Consumers can make decisions through information from sources with high credibility and trust [9]. Such emotional connections between influencers and audience are prerequisites for obtaining preference and trust in influencer marketing. The interaction between audience and influencers on social media platforms enhances their perceived approachability and authenticity to influencers [10]. The audience's familiarity and likability towards influencers determine their attitude towards influencer endorsements and brands, eventually strengthening the audience's trust in the brand and turning them into customers or potential customers. Therefore, influencer marketing depends on the continuous maintenance of relationships with the follower groups.

From the audience's perspective, the communication of social media influencer marketing largely comes from content creation [4]. Influencers endorse the brand through their unique and personal content creation, including the narration of the brand and product experience to consumers. Their content is generally entertaining, knowledgeable and cultural, and consistent with their personalities [11]. Different content characteristics will stimulate the audience's different emotions and behavioral intentions. Many studies explained the leading antecedents of influencer marketing to audience guidance, including brand positioning, sponsorship disclosure, and the characteristics of influencers [11, 12]. However, making audiences immerse in storytelling and interaction in content creation also means significant to social media influencers, especially in rich media (e.g., video platforms) [13]. By telling real stories and exciting narratives mixed with brand promotion-related content, more followers are willing to interact with influencers and learn about products or services. In this way, influencers can guide followers to the product and brand and create enjoyable content, reducing the persuasive intention perceived by the audience.

\subsection{Brand engagement}

Social media in Web 2.0 has expanded the way of branding information dissemination. Therefore, brand engagement in social media has increasingly attracted attention from both companies and scholars [14]. Brand engagement refers to the degree of positively valenced brand-related cognitional, emotional and behavioral investment in a brand [15]. From this basis, brand engagement is generally considered a multidimensional structure with cognitive, emotional, and behavioral dimensions. Brand engagement represents a higher level of customer's psychological and behavioral performance for the brand or company rather than merely the customer's consumption [16]. Brand engagement is a strategic way to create, develop and enrich customer relationships and achieve business performance. Prior researches suggest that brand engagement has various benefits for companies, e.g., a long-term relationship between the brand and customers, purchasing products or services more frequently, willingness to pay a premium price, and intentions to co-create and co-develop [17].

Companies adopt influencer marketing strategies to let social media influencers attract potential customers, encourage them to interact with brands, and establish good relationships with consumers [18]. Influencer marketing contributes to the brands through the genuine and lasting relationship with the audience on social media and their generated content. Unlike mere purchase, influencer marketing emphasizes recognitional and emotional guidance towards the brand. Brand engagement refers to a channel for co-creating activities [19], a sustainable emotional bonding between the brand and consumers. A fully engaged customer would be a cocreator and a brand promoter. Thus, brand engagement has become an essential indicator for evaluating influencer marketing effectiveness [7].

\section{PARASOCIAL RELATIONSHIP, SOURCE CREDIBILITY, AND BRAND CREDIBILITY}

The parasocial interaction theory explains the audience's one-side response and reception with media characters during media consumption [20, 21]. It describes the parasocial interaction as illusory human-tohuman interactions between audience and a performer on media. Parasocial relationship is illusory accompanying or friend-like relationships created between audiences and a performer, though relationship and interactions are not mutual [21, 22]. Parasocial relationships establish when individuals are constantly exposed to the characters in the various media environments and repeat parasocial interactions. Parasocial relationship interpretation can also apply to consumer-influencer relationships [23]. Influencer marketing relies on social media platforms, where the audience's parasocial relationship with 
influencers is formed through one-side parasocial interaction, e.g., watch, like, repost, and comment. Compared with traditional celebrity endorsements, influencer marketing emphasizes meeting on an equal basis and establishing intimate connections and relationships with other social media users through constant parasocial interactions. The parasocial relationship is a long-term response like rituals, which continue after media consumption and accompany the audience's lives. Eventually, it forms emotional responses, including trust and attachment.

The parasocial relationship between audience and influencers will further affect willingness to accept advertisement messages published by influencers and the attitudes and behaviors towards the brands endorsed by influencers. After repeated parasocial interactions, parasocial relationships will enhance to different stages. Specifically, the persuasion of influencers' communication increases when parasocial relationships reach a sufficiently high stage [24]. The strength of the parasocial relationship between influencers and followers is essential for influencer marketing performance. From the perspective of credibility theory, the parasocial relationship between audience and influencers affects the establishment of perceived credibility [25]. Source credibility has been widely used in influencer marketing research to determine whether the sender or source of information is persuasive and trustworthy. The concept of source credibility refers to the professionalism and credibility of influencers as a source messenger and the effectiveness of persuasive communication [26]. When the audience and the influencer establish a parasocial relationship, the audience regards the influencer as a friend, as well as an information source continuously influencing the audience's information reception. Because the source credibility determines the consumer's perception of the value of information, the credibility of the information source is often used to measure the degree to which consumers believe the product and service information provided by the influencer is trustworthy [27]. The intimacy and understanding that the audience gains through parasocial relationships enhance the perceived credibility of the influencers' information and their brand promotion [28]. Based on the discussion above, the first research proposition is the following:

P1: The parasocial relationship between the influencer and the audience positively affects the source credibility

Brand credibility refers to the customers' perception of the willingness and ability of the enterprise to realize the promised value [29]. Brand credibility is based on reliable knowledge from various marketing channels. On social media, where there are massive sources of information to judge brands, consumers tend to seek knowledge and information about the perceived quality of brands and products from trusted influencers to reduce risks and information costs. Therefore, brands actively invite influencers on media websites to participate in events or spread brand messages, and influencers will selectively work with their favorite brands to maintain their authenticity and credibility. Signal theory supports that the spokesperson's credibility can transfer to the brand's credibility [30]. Gong and Li [27] argued that the credibility of sources can promote endorsement effects in the context of parasocial interaction between fans and celebrities. Research by Jin and Muqaddam [31] indicates that influencers can use their impacts to increase the audience's perceived credibility, likeability, and attractiveness towards the brand. Therefore, this study has the second research proposition:

P2: Source credibility positively affects brand credibility

Brand credibility is the sum of cognition and emotion of the interaction between the customer and the provider regarding the brand's stability [29]. Brand engagement literature suggests that customer's brand engagement is driven by multiple motivations [3]. Brand credibility as a brand-related emotional motivation positively affects the formation of customer engagement behavior [32]. Brands with a good reputation and high brand equity are more likely to induce positive customer engagement [16]. Brand credibility positively affects consumers' perceptions and emotional bonding to the brand, which are the antecedent of beneficial marketing results, including future connection with the brand and willingness to participate in a collaborative online community [33]. Therefore, this study has the third proposition:

P3: Brand credibility positively affects brand engagement

\section{INFLUENCER CONTENT IMMERSION AND BRAND CONTENT ENJOYMENT}

On social media, users mainly follow others because they are interested in other people's lives and desire enjoyment, pleasure, and social recognition. The audience's recognition and pleasure toward the knowledge of a specific subject and the professionallygenerated content establish their attitude towards influencers [4]. When endorsing the brand, influencers experience the product before consumers and present interactive content about the information and opinion for the audience, so consumers can gain a virtual product experience before purchasing.

Immersion explains how consumers process and interact with information in content generated by influencers [34]. When people participate in experienceenriching and fulfilling activities, they will enter into a psychological state of being fully immersed, which is named 'flow' [35]. In the context of social media 
interaction, immersion is defined as being fully immersed in a social media environment and focusing on content narrative and media informative scene, embodied in loss of self-consciousness and the intrinsically enjoyable and self-reinforcing aspects of flow. The immersion state of psychological travel to the narratives results from the interaction of the external scenario and one's subjective cognition [36]. Influencer marketing generally focuses on more specific topics and market segments, and they endorse the brand with individualistic, intimate forms of self-expression [8, 18]. Influencer-created content provides a virtual experience of products or services that allows consumers to immerse themselves in media content. Immersive experience can promote people to process media information, thereby maintaining a longlasting memory. Additionally, immersion in the online environment will enhance the positive audience's emotions and positive attitude towards brand endorsement. Being immersed in the narratives and virtual experiences give consumers delighted feelings and ultimately produces good brand evaluations [37]. Therefore, this study proposes:

P4: Immersion of influencer content positively affects brand content enjoyment

Brand content enjoyment represents the audience's favor of brand-related information in influencer marketing while immersing in the content [38]. The audience has potential emotively-driven, experiential needs, including seeking recognition by looking for branded content that matches their preferences and continuously interacting with hedonic content [39]. The influencer's content serves as a guide and arouses the audience's interest in brand-related content, stimulating consumers' positive emotions and willingness to learn about the brand. The aroused positive emotions will enhance the audience's willingness to purchase, share, and participate in co-creation [40]. On this basis, the fifth proposition is presented:

P5: Brand content enjoyment positively affects brand engagement

Building on the literature review, this study developed a model for exploring the mechanism of influencer marketing affecting brand engagement, as represented in Figure 1. From the psychological process of brand engagement building, this model explains the linkage between the parasocial relationship with influencers, source credibility, brand credibility, video content immersion, brand content enjoyment, and brand engagement.

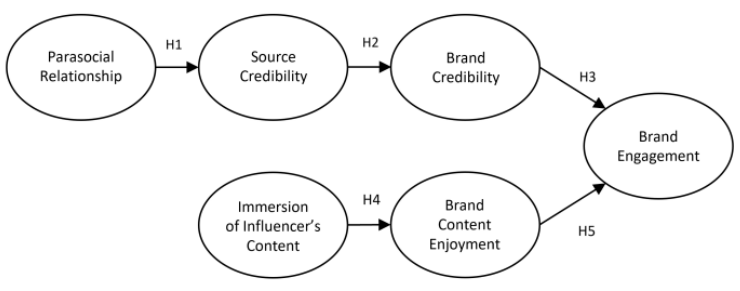

Figure 1 Conceptual model.

\section{CONCLUSION}

In summary, the rise of influencer marketing is an innovation of brand marketing models and a new way of reshaping social media users' reception and consumption. Therefore, it is necessary to have a new model to analyze the psychological mechanism of the audience's internal guidance from influencer to brand. This paper explores how influencer marketing in social media affects customer engagement based on the parasocial relationship, credibility, and immersion theory. An integrated model is built accordingly, showing that influencer marketing enhances customer engagement through two directions on social media platforms. One is to promote the source's credibility by establishing a parasocial relationship and transforming it into credibility for the brand, thereby strengthening the brand engagement. The other is through the audience's immersion in consuming the narrative and performance of influencers' content on social media. Immersion in influencers' content makes the audience enjoy the brand information in the content and eventually cultivates brand engagement. The above discussions deepen the understanding of brand engagement formation and transmission on social media platforms. However, it is necessary to refine the context of social media platforms, influencers, and brand positioning in the future quantitative analysis to obtain meaningful solutions for the brand. Additionally, it should be noted that this article does not integrate a complete theoretical background, so there are still more potential perspectives and theories to explain the impact of influencer marketing to brand engagement.

These results offer a guideline for future research on the psychological impact of influencer marketing on brand engagement. Influencer marketing should be examined from the perspective of the parasocial relationship and content immersion. This research also presents some managerial implications for brand managers who implement strategic decisions in influencer marketing. Brand managers should search for influencers who continuously produce high-quality content and have loyal followers. When cooperating with influencers congruent with the brand image, brand managers should actively communicate with them to ensure that they could present fun and immersive content. 


\section{REFERENCES}

[1] Vrontis, D., et al., Social media influencer marketing: a systematic review, integrative framework and future research agenda. International Journal of Consumer Studies, 2021: p. $1-28$.

[2] InfluencerMarketingHub. The State of Influencer Marketing 2021: Benchmark Report. 2021 [cited 2021 June 30]; Available from: https://influencermarketinghub.com/influencermarketing-benchmark-report-2021/.

[3] Hollebeek, L.D. and K. Macky, Digital content marketing's role in fostering consumer engagement, trust, and value: Framework, fundamental propositions, and implications. Journal of Interactive Marketing, 2019. 45: p. 27-41.

[4] Lou, C. and S. Yuan, Influencer Marketing: How Message Value and Credibility Affect Consumer Trust of Branded Content on Social Media. Journal of Interactive Advertising, 2019. 19(1): p. 58-73.

[5] Trivedi, J.P., Effect of Influencer Marketing on Online Impulse Purchase: The Mediating Role of Consumer-Brand Engagement. Journal of Electronic Commerce in Organizations (JECO), 2021. 19(3): p. 49-64.

[6] Cotter, K., Playing the visibility game: How digital influencers and algorithms negotiate influence on Instagram. New Media \& Society, 2019. 21(4): p. 895-913.

[7] Childers, C.C., L.L. Lemon, and M.G. Hoy, \#Sponsored \#Ad: Agency Perspective on Influencer Marketing Campaigns. Journal of Current Issues \& Research in Advertising, 2019. 40(3): p. 258-274.

[8] De Veirman, M., V. Cauberghe, and L. Hudders, Marketing through Instagram influencers: the impact of number of followers and product divergence on brand attitude. International journal of advertising, 2017. 36(5): p. 798-828.

[9] Xiao, M., R. Wang, and S. Chan-Olmsted, Factors affecting YouTube influencer marketing credibility: a heuristic-systematic model. Journal of Media Business Studies, 2018. 15(3): p. 188-213.

[10] Men, L.R. and W.-H.S. Tsai, Public engagement with CEOs on social media: Motivations and relational outcomes. Public Relations Review, 2016. 42(5): p. 932-942.

[11] Sokolova, K. and H. Kefi, Instagram and YouTube bloggers promote it, why should I buy? How credibility and parasocial interaction influence purchase intentions. Journal of Retailing and Consumer Services, 2020. 53.

[12] Ouvrein, G., et al., The web of influencers. A marketing-audience classification of (potential) social media influencers. Journal of Marketing Management, 2021: p. 1-30.

[13] Haenlein, M., et al., Navigating the New Era of Influencer Marketing: How to be Successful on Instagram, TikTok, \& Co. California Management Review, 2020. 63(1): p. 5-25.

[14] Gómez, M., C. Lopez, and A. Molina, An integrated model of social media brand engagement. Computers in Human Behavior, 2019. 96: p. 196206.

[15] Hollebeek, L.D., M.S. Glynn, and R.J. Brodie, Consumer brand engagement in social media: Conceptualization, scale development and validation. Journal of interactive marketing, 2014. 28(2): p. 149-165.

[16] Vivek, S.D., S.E. Beatty, and R.M. Morgan, Customer engagement: Exploring customer relationships beyond purchase. Journal of marketing theory and practice, 2012. 20(2): p. 122146.

[17] Brodie, R.J., et al., Consumer engagement in a virtual brand community: An exploratory analysis. Journal of business research, 2013. 66(1): p. 105114.

[18] Khamis, S., L. Ang, and R. Welling, Self-branding, 'micro-celebrity' and the rise of Social Media Influencers. Celebrity Studies, 2017. 8(2): p. 191208.

[19] Storbacka, K., et al., Actor engagement as a microfoundation for value co-creation. Journal of Business Research, 2016. 69(8): p. 3008-3017.

[20] Brown, W.J., Examining four processes of audience involvement with media personae: Transportation, parasocial interaction, identification, and worship. Communication Theory, 2015. 25(3): p. 259-283.

[21] Horton, D. and R. Richard Wohl, Mass communication and para-social interaction: Observations on intimacy at a distance. psychiatry, 1956. 19(3): p. 215-229.

[22] Dibble, J.L., T. Hartmann, and S.F. Rosaen, Parasocial interaction and parasocial relationship: Conceptual clarification and a critical assessment of measures. Human Communication Research, 2016. 42(1): p. 21-44.

[23]Jin, S.V. and E. Ryu, "I'll buy what she's \#wearing": The roles of envy toward and parasocial interaction 
with influencers in Instagram celebrity-based brand endorsement and social commerce. Journal of Retailing and Consumer Services, 2020. 55: p. 102121 .

[24] Tukachinsky, R. and G. Stever, Theorizing development of parasocial engagement. Communication Theory, 2019. 29(3): p. 297-318.

[25] Djafarova, E. and C. Rushworth, Exploring the credibility of online celebrities' Instagram profiles in influencing the purchase decisions of young female users. Computers in Human Behavior, 2017. 68: p. 1-7.

[26] Sternthal, B., R. Dholakia, and C. Leavitt, The persuasive effect of source credibility: Tests of cognitive response. Journal of Consumer research, 1978. 4(4): p. 252-260.

[27] Gong, W. and X. Li, Engaging fans on microblog: The synthetic influence of parasocial interaction and source characteristics on celebrity endorsement. Psychology \& Marketing, 2017. 34(7): p. 720-732.

[28] Chung, S. and H. Cho, Fostering parasocial relationships with celebrities on social media: Implications for celebrity endorsement. Psychology \& Marketing, 2017. 34(4): p. 481-495.

[29] Erdem, T. and J. Swait, Brand credibility, brand consideration, and choice. Journal of consumer research, 2004. 31(1): p. 191-198.

[30] Spry, A., R. Pappu, and T.B. Cornwell, Celebrity endorsement, brand credibility and brand equity. European journal of marketing, 2011.

[31] Jin, S.V. and A. Muqaddam, Product placement 2.0: "Do Brands Need Influencers, or Do Influencers Need Brands?". Journal of Brand Management, 2019. 26(5): p. 522-537.
[32] Perera, C.H., R. Nayak, and L.T.V. Nguyen, The impact of subjective norms, eWOM and perceived brand credibility on brand equity: application to the higher education sector. International Journal of Educational Management, 2021. 35(1): p. 63-74.

[33] Kumar, V. and A. Pansari, Competitive advantage through engagement. Journal of marketing research, 2016. 53(4): p. 497-514.

[34] Nelson, M.R., R.A. Yaros, and H. Keum, Examining the influence of telepresence on spectator and player processing of real and fictitious brands in a computer game. Journal of Advertising, 2006. 35(4): p. 87-99.

[35] Csikszentmihalyi, M., Flow: The Psychology of Optimal Experience. Design Issues, 1991. 8(1).

[36] Nakamura, J. and M. Csikszentmihalyi, The concept of flow, in Flow and the foundations of positive psychology. 2014, Springer. p. 239-263.

[37] Escalas, J.E., Self-referencing and persuasion: Narrative transportation versus analytical elaboration. Journal of Consumer Research, 2007. 33(4): p. 421-429.

[38] Hussain, S., et al., Examining the effects of celebrity trust on advertising credibility, brand credibility and corporate credibility. Journal of Business Research, 2020. 109: p. 472-488.

[39] van Doorn, J., et al., Customer Engagement Behavior: Theoretical Foundations and Research Directions. Journal of Service Research, 2010. 13(3): p. 253-266.

[40] Pansari, A. and V. Kumar, Customer engagement: the construct, antecedents, and consequences. Journal of the Academy of Marketing Science, 2017. 45(3): p. 294-311. 